\title{
Melatonin and 5-methoxytryptamine in non-metazoans
}

\author{
Rüdiger Hardeland
}

\author{
Institut für Zoologie und Anthropologie, Universität Göttingen, \\ Berliner Str. 28, 37073 Göttingen, Germany
}

(Received 11 January 1999; accepted 26 March 1999)

\begin{abstract}
Melatonin seems to be an almost ubiquitous substance, which has been detected not only in metazoans, but also in all major non-metazoan taxa investigated, including bacteria, dinoflagellates, euglenoids, trypanosomids, fungi, rhodophyceans, pheophyceans, chlorophyceans and angiosperms. Despite its vast abundance, little is known to date about its functions. Its presence is not necessarily associated with circadian rhythmicity, which is evident in yeast. Circadian rhythms of melatonin have been reported in non-metazoans only for several unicellular organisms and in one angiosperm. In dinoflagellates, which have been studied in the most detail, the effects on enzyme activities and on phase shifting are known, but the most spectacular actions concerning the stimulation of bioluminescence, changes in cytoplasmic $\mathrm{pH}$ and induction of resting stages, can be related to a metabolite of melatonin, the 5-methoxytryptamine; therefore, melatonin should also be considered as a source of other agonists. @ Inra/Elsevier, Paris
\end{abstract}

algae / angiosperms / melatonin / 5-methoxytryptamine / protozoa

Résumé - Mélatonine et 5-méthoxytryptamine chez les non-métazoaires. La mélatonine semble être une substance très répandue qui a été détectée non seulement chez les métazoaires, mais aussi dans la majorité des taxa de non-métazoaires, ce qui inclut les bactéries, les dinoflagellés, les eugléniens, les trypanosomes, les champignons, les rhodophycées, les phéophycées, les chlorophycées et les angiospermes. Malgré cette grande abondance, ses fonctions sont très peu connues. Sa présence n'est pas nécessairement associée à une rythmicité circadienne, comme cela devient évident chez les levures. Des rythmes circadiens de mélatonine ont été décrits chez les non-métazoaires, mais uniquement chez quelques unicellulaires et chez une angiosperme. Chez les dinoflagellés, qui ont été étudiés plus en détail, les effets sur des activités enzymatiques et des décalages de phase sont connus, mais les actions les plus spectaculaires qui concernent la stimulation de la bioluminescence, les changements de $\mathrm{pH}$ cytoplasmique et l'induction des états de repos, peuvent être reliées au métabolite de la mélatonine, le 5-méthoxytryptamine ; la mélatonine doit donc être considérée comme une source d'autres agonistes. (O Inra/Elsevier, Paris

algue / angiospermes / mélatonine / 5-méthoxytryptamine / protozoaire

E-mail: rhardel@gwdg.de 


\section{INTRODUCTION}

Since the first demonstration of melatonin (= MLT) outside of the metazoa [32, 33 ], this indoleamine has been detected in numerous organisms belonging to various major taxa (tables $I$ and $I I$ ), including procaryotes, evolutionarily different lines of eucaryotic unicellular organisms and macroalgae, as well as higher plants and fungi. This large body of evidence permits the statement that melatonin is an (almost) ubiquitous, or highly conserved, substance. Ubiquity frequently indicates fundamental biological significance. This may be so in the case of melatonin, although the answers to the question of what these fundamental properties are can only be given tentatively at the present state of our knowledge.

In the majority of non-metazoan organisms, investigations have been restricted to the mere demonstration of the presence of melatonin. Moreover, in terms of function, a general, common theme is, at least, not clearly evident from a comparison of the many different species. By projecting the findings obtained in mammals or other vertebrates, investigators frequently tend to assume its function as a mediator of dark signals, with possible implications in the control of circadian rhythmicity and seasonality. Although some parallels to mammalian systems can indeed be found, for example in dinoflagellates, such a generalization seems to be currently unjustified. In this context, one should be aware that, even in mammals, melatonin does not always uniformly serve the function of conveying dark signals: in the rodent Harderian gland, high levels of melatonin, associated with the presence of a photocatalyst, protoporphyrin IX, do not exhibit circadian amplitudes large enough for such a role $[29,30]$. In various invertebrate animals, melatonins even exhibit diurnal peaks (summarized in [15, 41]).

\section{MELATONIN AND CIRCADIAN RHYTHMICITY IN NON-METAZOANS}

Although the presence of melatonin has been demonstrated in a comparably large number of non-metazoan species, there are only very few organisms in which this indoleamine has been shown to oscillate in a circadian fashion. This is the case in the dinoflagellate Gonyaulax polyedra, in which melatonin rises strongly directly after the onset of the dark phase, and in which rhythmicity persists in constant darkness (= DD) $[5,17,33]$. Nocturnally peaking diurnal rhythms of melatonin were also found in Euglena gracilis and in several unicellular chlorophyceans, such as Dunaliella tertiolecta and various Chlamydomonas species (Balzer I. et al., unpubl. data). In an aerobic photosynthetic bacterium, Erythrobacter longus, melatonin levels were shown to be much higher in darkness than in light [37]; however, circadian rhythmicity was not demonstrated in that paper. The difference between melatonin levels in light and darkness may already suffice for an action as a dark mediator regardless of whether melatonin may be produced at a higher rate during darkness, may be photocatalytically destroyed in the light or whether a circadian oscillator may be present in this procaryote. This possibility remains, however, to be further substantiated on the basis of physiological responses to the indoleamine.

The only higher plant in which rhythmicity of melatonin has been thoroughly investigated is the dicot Chenopodium rubrum, a well-known short-day plant appearing to be particularly suitable for studying the possibility of a role in photoperiodism. Again, the indoleamine exhibited a high-amplitude rhythm with a nocturnal peak [23]. Other data from that group showing changes in phase position after transfer to a different photoperiod and persistence in DD have been presented at recent 
Table I. Melatonin and other methoxyindoles in various non-metazoan taxa.

\begin{tabular}{|c|c|c|c|}
\hline Taxon/Organism & Compound & Detection & References \\
\hline \multicolumn{4}{|l|}{ Procaryonta } \\
\hline Rhodospirillum rubrum & MLT & RIA & [28] \\
\hline Erythrobacter longus & MLT & RIA,TLC & {$[37]$} \\
\hline \multicolumn{4}{|l|}{ Euglenoidea } \\
\hline Euglena gracilis & MLT,5MT,5ML & RIA,HPLC-ECD & $\left(\mathrm{B}^{*}\right)$ \\
\hline \multicolumn{4}{|l|}{ Trypanosomida } \\
\hline Trypanosoma cruzi & MLT & RIA & $\left(\mathrm{A}^{*}\right)$ \\
\hline \multicolumn{4}{|l|}{ Dinoflagellata } \\
\hline Gonyaulax polyedra & MLT,5MT,5ML & $\begin{array}{l}\text { RIA,HPLC-ECD, } \\
\text { HPLC-FD }\end{array}$ & $\begin{array}{l}{[5,12,13,15,17,} \\
31,32,33]\end{array}$ \\
\hline Alexandrium lusitanicum & MLT,5MT,5ML & RIA,HPLC-ECD & $\left(\mathrm{F}^{*}\right)$ \\
\hline Ceratium horridum & $5 \mathrm{MT}, 5 \mathrm{ML}$ & HPLC-ECD & $\left(F^{*}\right)$ \\
\hline Amphidinium carterae & MLT,5MT,5ML & HPLC-ECD & $\left(\mathrm{F}^{*}\right)$ \\
\hline Pyrocystis lunula & MLT & $\mathrm{ICC}$ & $\left(\mathrm{B}^{*}\right)$ \\
\hline Noctiluca scintillans & MLT & RIA & $\left(B^{*}\right)$ \\
\hline
\end{tabular}

Ciliata

Tetrahymena thermophila

$5 \mathrm{MT}$

HPLC-ECD

Rhodophyceae

Gracilaria tenustipitata

Palmaria palmata

MLT

MLT

Porphyra umbilicalis

MLT,5MT,5ML

ICC,HPLC-ECD

$\left(\mathrm{B}^{*}\right),\left(\mathrm{L}^{*}\right)$

ELISA,ICC

[26], $\left(\mathrm{B}^{*}\right)$

ELISA,HPLC-ECD,

$[8,26]$

Chondrus crispus

MLT,5MT,5ML

HPLC-FD

Phaeophyceae

Pterygophora californica

Laminaria digitata

MLT,5ML

MLT

HPLC-ECD

Petalonia fascia

MLT,5MT,5ML

RIA,ELISA,HPLC-ECD $[11,42]$

HPLC-ECD

$\left(\mathrm{L}^{*}\right)$

HPLC-ECD

Chlorophyceae

Acetabularia acetabulum

Dunaliella tertiolecta

MLT

MLT

RIA,ICC,HPLC-UVD

$\left(\mathrm{B}^{*}\right)$

Chlamydomonas spp.

MLT

RIA

$\left(\mathrm{B}^{*}\right)$

RIA

(B*)

Angiospermae

species of ten dicot and six MLT

monocot families; for

list of species see ref. [4]

RIA,HPLC-ECD,

$[10,20,22$,

HPLC-FD,HPLC-MS $\quad$ 23, 24, 40]

LC-MS

Fungi

Saccharomyces cerevisiae Neurospora crassa

MLT,5MT,5ML

HPLC-ECD

[36]

MLT

HPLC-ECD

(B*)

* Unpubl. data (except abstracts, theses, lab. reports) by A = Acuña-Castroviejo D.; B = Balzer I. et al.; F = Fuhrberg B., Hardeland R.; L = Lüning K. et al. 


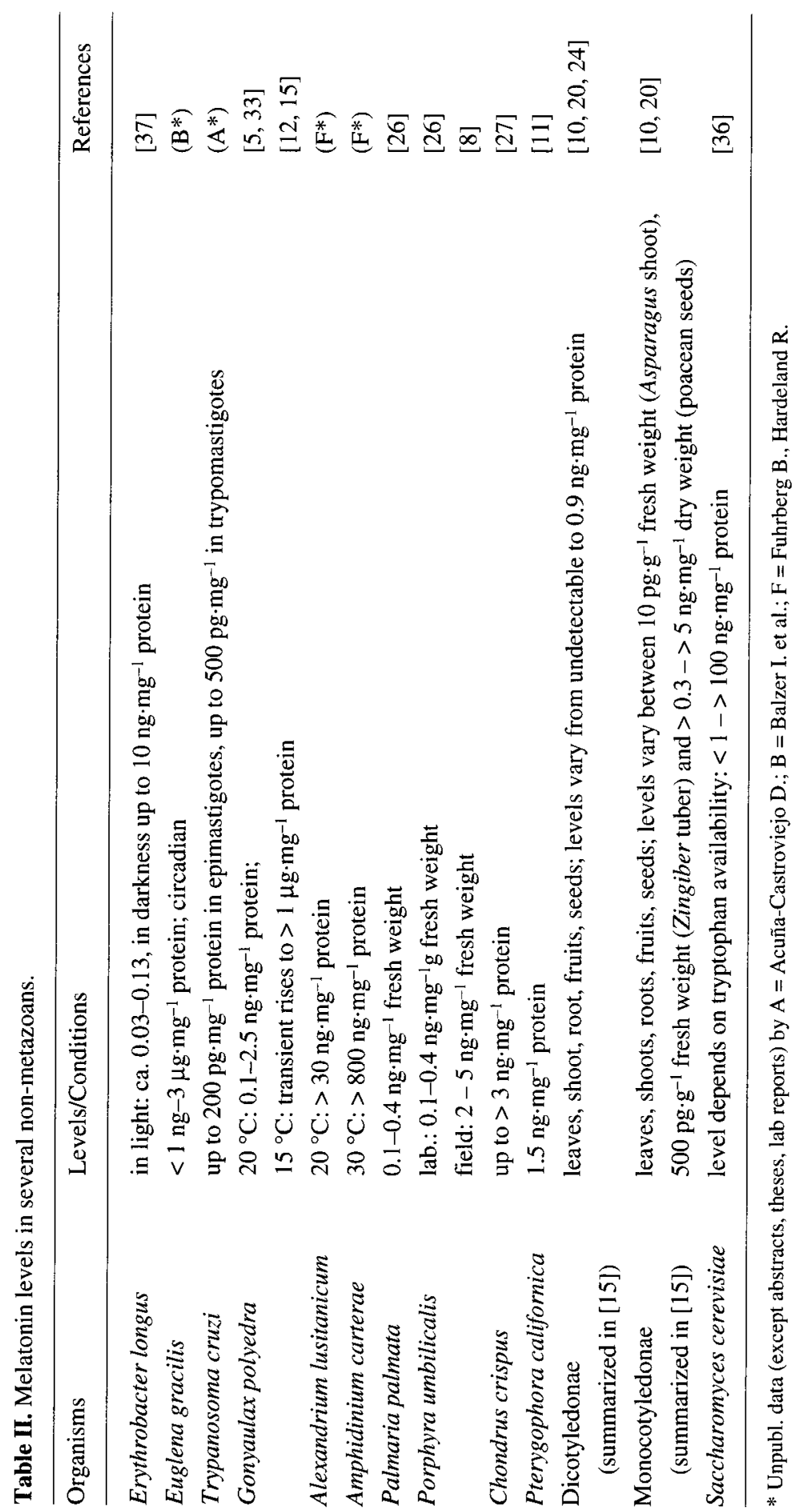


meetings, but this information was not included in the respective abstracts, presumably because the data were cautiously regarded as being preliminary. Nevertheless, it seems likely that a true circadian rhythm exists in this species. A nocturnally peaking rhythm was also found in another dicot, the tomato, Lycopersicon esculentum (Balzer I. et al., unpubl. data).

Elevated levels in darkness are, of course, an essential condition for a role as a mediator of dark signals. Another aspect is its capability of inducing phase shifts in circadian rhythms. This has been demonstrated under DD conditions for bioluminescence rhythms in a few dinoflagellates. A complete phase-response curve was only obtained in Pyrocystis acuta, in which the advanced part was more pronounced than the delayed portion (Fischer J., Hardeland R., unpubl. data). Phase-shifting was also observed in Gonyaulax polyedra, but owing to other intentions of the study [1], this aspect was not followed systematically; when given in the middle of the day, melatonin caused phase delays of a few hours. Similar data were obtained for Gonyaulax spinifera (Hardeland R., Mbachu E.M., unpubl. data).

Although circadian rhythmicity of melatonin exists in non-metazoans, this does not allow for generalizations. The clearest counter-example is presumably Saccharomyces cerevisiae, which contains remarkably high amounts of melatonin and other methoxyindoles [36], but for which no indication of circadian rhythmicity exists, neither for these indoleamines nor for other functions. In a brown alga, Pterygophora californica, the expression of a circadian rhythm in melatonin concentration seems to be conditional and, during long days, a bimodal pattern with both nocturnal and diurnal peaks is observed [42].

\section{PROBLEMS OF MELATONIN DETECTION IN NON-METAZOANS}

Some of the reasons for the imbalance between the demonstration of the presence of melatonin in very many species and hard data on circadian and seasonal patterns in only a few of them are of a technical nature. In many plants and unicellular organisms, melatonin is readily destroyed during its extraction from the cell or tissue material, and elaborate preservative procedures have to be applied in order to obtain acceptable rates of recovery $[31,33]$. This seems to be particularly difficult in material from some eucaryotic photoautotrophs, even under strict occlusion from light. On the contrary, quantitative extraction is easily possible in a heterotroph such as yeast [36] and also in Erythrobacter longus [37], an aerobic photosynthetic bacterium which is not fully photoautotroph. Since melatonin easily undergoes reactions with several free radicals [15-17, 35], instability during extraction may reflect the electron exchange with radicals and with components of electron transport chains and may, therefore, be largely caused by chloroplasts. Moreover, the problem of instability has to be solved again for all organisms that are to be studied, and this can only be achieved on the basis of thorough determinations of recovery. This has been performed in detail in only two photoautotrophs, namely in the dinoflagellate Gonyaulax polyedra $[31,33]$, and in the angiosperm Chenopodium rubrum [23].

Measurements of recovery are not easily performed in massive plant tissues, because the externally added melatonin cannot be mixed thoroughly with the cell material before homogenization. For this reason, many determinations of endogenous melatonin in parts from higher plants or macroalgae, in which the yield is unknown, may still be largely underestimated. An additional problem in angiosperms, macroalgae and also in some fungi (but not in yeast) 
results from the distribution within the tissue or even the cell, and more precisely from the partition of melatonin between the cytoplasm, the large central vacuole, and cell wall/apoplast. Usually, data are presented on the basis of fresh weight or protein as reference values. This does not, however, provide any information on the effective cytoplasmic concentration of the indoleamine. As long as we do not know how much of the melatonin detected is present extracellularly in the apoplast and how much is present in the vacuole, making up by far the largest part of the plant cell, any considerations of physiological levels remain impossible.

\section{RESPONSES TO MELATONIN}

Our current knowledge on the effects of melatonin in non-metazoans is still scarce (cf. table III). In dinoflagellates the effects are often found only at very high concentrations $(0.1 \mathrm{mM}$ and higher; in Crypthecodinium, even $10 \mathrm{mM}$ have been used [38, 39]). Moreover, the effects can be conditional, as in Gonyaulax polyedra, in which the encystment response occurs only at a lower temperature $[2,13,14]$; such a treatment leads to enormous accumulations of melatonin anyway (transiently more than $1 \mathrm{mM}$ ) and finally to high concentrations of 5-methoxytryptamine (=5MT) [12, 15]. Since $5 \mathrm{MT}$ is much more efficient as a regulator of various functions, for example as an inducer of asexual cysts, as a stimulator of bioluminescence and cytoplasmic acidification $[2,3,13,14,17]$, the question remains as to whether all the other actions are not also due to 5MT. Recent findings in Crypthecodinium cohnii [38, 39], showing increases in calcium influx and in the formation of inositol phosphates, are affected by the problem that, apart from the extremely high concentrations required, the dose-responses to melatonin and 5MT are relatively similar, despite the strong difference in cyst-inducing efficiency.
The effects of melatonin in other nonmetazoans are only partially interpretable. There is, at least, one common effect discernible from the comparison of the ciliate, Stentor, and the two monocots, Haemanthus and Allium. This is namely an influence on the cytoskeleton, which is also found in mammalian cells and which may relate to the binding of melatonin to calmodulin [9]. This may be, in fact, a wide-spread action, which has been much neglected in the past. It is possible that the effects on growth, or on the release of gametes, as found in several algae (table III), or perhaps even the suppressive effects on flower induction in Chenopodium can be interpreted on this basis. The expectancy for a short-day plant would have been that melatonin, if involved in photoperiodism, should favour flowering. The contrary was also observed, with a synthetic melatonin analogue, CGP 52608 [24]. There is, however, a promising finding in the brown alga Pterygophora, in which melatonin induced the formation of a new blade, as otherwise found during the annual cycle [42], which is a possible hint for melatonin-controlled seasonality.

\section{OCCURRENCE OF AND RESPONSES \\ TO 5-METHOXYTRYPTAMINE}

In the majority of the investigations, methoxyindoles other than melatonin were not determined. However, when chromatographic techniques were applied, it turned out that most non-metazoans tested also contain high amounts of 5MT and of 5-methoxytryptophol (= 5ML) (cf. table I). This is the case in phylogenetically different lines of protozoa and macroalgae as well as in yeast. While strong effects of 5ML have not been reported in non-metazoans, except for extreme concentrations ( $10 \mathrm{mM})$ in Crypthecodinium cohnii [39], 5MT has proven to be a very efficient agonist in various dinoflagellates (table IV). At concentrations below $10 \mu \mathrm{M}$ (levels which are frequently 


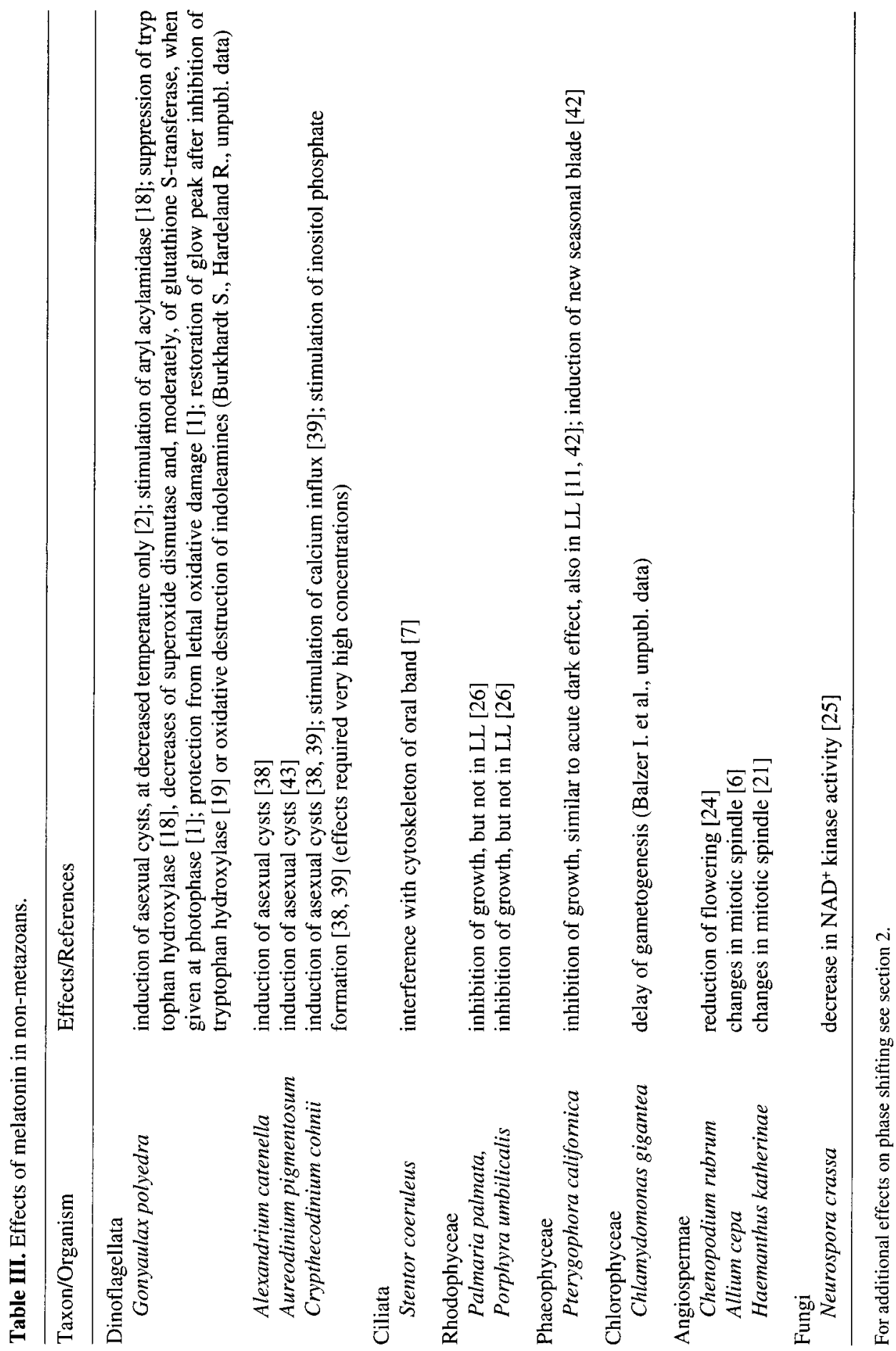


Table IV. Effects of 5-methoxytryptamine in various dinoflagellates.

\begin{tabular}{ll}
\hline Species & Effects/References \\
\hline Gonyaulax polyedra* & $\mathrm{c}[2,14,17], \mathrm{a}[17], \mathrm{b}[3,13,14]$ \\
Gonyaulax spinifera* & $\mathrm{b}$ (Hardeland R., Mbachu E.M., unpubl. data) \\
Alexandrium tamarense* & $\mathrm{c}$ [43], a, b (Hardeland R., unpubl. data) \\
Alexandrium spec. 146\#* & $\mathrm{c}, \mathrm{a}, \mathrm{b}$ (Hardeland R., Mbachu E.M., unpubl. data) \\
Alexandrium lusitanicum & $\mathrm{c}$, a (Hardeland R., unpubl. data) \\
Alexandrium spec. 155\# & $\mathrm{c}$, a (Hardeland R., unpubl. data) \\
Alexandrium catenella & $\mathrm{c}[38]$ \\
Aureodinium pigmentosum & $\mathrm{c}[43]$ \\
Gymnodinium simplex & $\mathrm{c}[43]$ \\
Gymnodinium catenatum & $\mathrm{i}$ (Hardeland R., unpubl. data) \\
Crypthecodinium cohnii & $\mathrm{c}[38,39,43]$ \\
Scripsiella trochoidea & $\mathrm{c}[43]$ \\
Prorocentrum, many species & $\mathrm{i}$ (Hardeland R., unpubl. data) \\
Symbiodinium spec. & formation of coccoid, cyst-like stage, as formed in coelenterate \\
& hosts [34]
\end{tabular}

Effects: immobilization without encystment $(=\mathrm{i})$; induction of asexual cysts $(=\mathrm{c})$; cytoplasmic acidification $(=\mathrm{a})$; stimulation of bioluminescence $(=\mathrm{b})$. * Bioluminescent species; \# BAH-ME collection numbers.

attained in dinoflagellates) 5MT stimulates the formation of asexual cysts, cellular immobilization, cytoplasmic acidification and light emission in bioluminescent species. 5MT was also shown to be required for the expression of the circadian glow peak in Gonyaulax polyedra [19]. The conversion of melatonin to 5MT, due to the observed induction of a melatonin-deacetylating aryl acylamidase, is suggested to be the crucial step in the encystment response of this species $[12,15,17,18]$. Since no high-affinity binding sites for melatonin were detected in Gonyaulax (Masson-Pévet M., Balzer I., unpubl. data), signalling may involve 5MT formation; this metabolite has strong effects on proton transfer from an acidic vacuole system, and the effects on encystment as well as on bioluminescence can be mimicked by protonophores $[13,15,17]$. Moreover, inhibitors of monoamine oxidase, which cause the accumulation of 5MT to cyst-inducing concentrations $[12,15]$, also elicited the two responses $[13-15,17]$. Therefore, the question is how findings on rises in 5MT, signalled by proton transfer and effects on calcium and inositol phos- phates, as found in Crypthecodinium [38, 39], can be matched; that is, in which temporal and functional sequence such events will interact.

\section{REFERENCES}

[1] Antolín I., Obst B., Burkhardt S., Hardeland R., Antioxidative protection in a high-melatonin organism: The dinoflagellate Gonyaulax polye$d r a$ is rescued from lethal oxidative stress by strongly elevated, but physiologically possible concentrations of melatonin, J. Pineal Res. 23 (1997) 182-190.

[2] Balzer I., Hardeland R., Photoperiodism and effects of indoleamines in a unicellular alga, Gonyaulax polyedra, Science 253 (1991) 795-797.

[3] Balzer I., Hardeland, R., Stimulation of bioluminescence by 5 -methoxylated indoleamines in the dinoflagellate, Gonyaulax polyedra, Comp. Biochem. Physiol. 98C (1991) 395-397.

[4] Balzer I., Hardeland R., Melatonin in algae and higher plants - Possible new roles as a phytohormone and antioxidant, Bot. Acta 109 (1996) 180-183.

[5] Balzer I., Poeggeler B., Hardeland R., Circadian rhythms of indoleamines in a dinoflagellate, Gonyaulax polyedra: Persistence of melatonin rhythm in constant darkness and relationship to 5-methoxytryptamine, in: Touitou Y., Arendt J., 
Pévet P. (Eds.), Melatonin and the Pineal Gland - From Basic Science to Clinical Application, Excerpta Medica, Amsterdam, 1993, pp. 183-186.

[6] Banerjee S., Margulis L., Mitotic arrest by melatonin, Exp. Cell Res. 78 (1973) 314-318.

[7] Banerjee S., Kerr V., Winston M., Kelleher J.K., Margulis L., Melatonin: inhibition of microtubule-based oral morphogenesis in Stentor coeruleus, J. Protozool. 19 (1972) 108-113.

[8] Bartsch I., Lüning K., Kadel P., Laboratory and field investigations of the melatonin content in the intertidal marine macroalga Porphyra umbilicalis, Biol. Rhythm Res. (1999) in press.

[9] Benítez-King G., Antón-Tay F., Calmodulin mediates melatonin cytoskeletal effects, Experientia 49 (1993) 635-641.

[10] Dubbels R., Reiter R.J., Klenke E., Goebel A., Schnakenberg E., Ehlers C., Schiwara H.W., Schloot W., Melatonin in edible plants identified by radioimmunoassay and by high performance liquid chromatography-mass spectrometry, J. Pineal Res. 18 (1995) 28-31.

[11] Fuhrberg B., Balzer I., Hardeland R., Werner A., Lüning K., The vertebrate pineal hormone melatonin is produced by the brown alga Pterygophora californica and mimics dark effects on growth rate in the light, Planta 200 (1996) 125-131.

[12] Fuhrberg B., Hardeland R., Poeggeler B., Behrmann G., Dramatic rises of melatonin and 5-methoxytryptamine in Gonyaulax exposed to decreased temperature, Biol. Rhythm Res. 28 (1997) 144-150.

[13] Hardeland R., The presence and function of melatonin and structurally related indoleamines in a dinoflagellate, and a hypothesis on the evolutionary significance of these tryptophan metabolites in unicellulars, Experientia 49 (1993) 614-622.

[14] Hardeland R., Balzer I., Chronobiology in unicells: Multiplicity of frequencies, non-oscillatory states, photoperiodism and effects of biogenic amines, Trends Comp. Biochem. Physiol. 1 (1993) 71-87.

[15] Hardeland R., Fuhrberg B., Ubiquitous melatonin - Presence and effects in unicells, plants and animals, Trends Comp. Biochem. Physiol. 2 (1996) 25-45.

[16] Hardeland R., Reiter R.J., Poeggeler B., Tan D.-X., The significance of the metabolism of the neurohormone melatonin: Antioxidative protection and formation of bioactive substances, Neurosci. Biobehav. Rev. 17 (1993) 347-357.

[17] Hardeland R., Balzer I., Poeggeler B., Fuhrberg B., Uría H., Behrmann G., Wolf R., Meyer T.J., Reiter R.J., On the primary functions of melatonin in evolution: Mediation of photoperiodic signals in a unicell, photooxidation and scavenging of free radicals, J. Pineal Res. 18 (1995) 104-111.
[18] Hardeland R., Fuhrberg B., Burkhardt S., Poeggeler B., Lax P., Aryl acylamidase and tryptophan hydroxylase, two key enzymes of 5-methoxytryptamine formation in the dinoflagellate Gonyaulax polyedra, are regulated by a circadian oscillator, by melatonin and by temperature, in: Hocevar A., Crepinšek Z., KajfezBogataj L. (Eds.), Biometeorology 14, Pt. 2, Vol. 2, Int. Soc. Biometeorol., Ljubljana, 1997, pp. 278-285.

[19] Hardeland R., Burkhardt S., Antolín I., Fuhrberg B., Coto-Montes A., Melatonin and 5-methoxytryptamine in the bioluminescent dinoflagellate Gonyaulax polyedra: Restoration of the circadian glow peak after suppression of indoleamine biosynthesis or oxidative stress, Adv. Exp. Med. Biol. (1999) in press.

[20] Hattori A., Migitaka H., Iigo M., Itoh M., Yamamoto K., Ohtani-Kaneko R., Hara M., Suzuki T., Reiter R.J., Identification of melatonin in plants and its effects on plasma melatonin levels and binding to melatonin receptors in vertebrates, Biochem. Mol. Biol. Int. 35 (1995) 627-634.

[21] Jackson W.T., Regulation of mitosis. II. Interaction of isopropyl $\mathrm{N}$-phenylcarbamate and melatonin, J. Cell Sci. 5 (1969) 745-755.

[22] Kolár J., Machácková I., Illnerová H., Prinsen E., Van Dongen W., Van Onckelen H.A., Melatonin in higher plant determined by radioimmunoassay and liquid chromatography-mass spectrometry, Biol. Rhythm Res. 26 (1995) 406.

[23] Kolár J., Machácková I., Eder J., Prinsen E., Van Dongen W., Van Onckelen H., Illnerová H., Melatonin: occurrence and daily rhythm in Chenopodium rubrum, Phytochemistry 44 (1997) 1407-1413.

[24] Kolár J., Machácková I., Johnson C.H., Effect of a melatonin analogue CGP 52608 on the photoperiodic flower induction in a short-day plant, Chenopodium rubrum, Biol. Rhythm Res. (1999) in press.

[25] Kubis H.-P., Balzer I., Hardeland R., Effects of 1,2-dihydro-4-hydroxy-6-methoxy- $N$-methyl quinoline in relation to circadian rhythms of $\mathrm{NAD}^{+}$kinase and NADP ${ }^{+}$autoreduction in $\mathrm{Neu}-$ rospora crassa and bioluminescence in Gonyaulax polyedra, Comp. Biochem. Physiol. 102C (1992) 97-101.

[26] Lorenz M., Lüning K., Detection of endogenous melatonin in the marine red macroalgae Porphyra umbilicalis and Palmaria palmata by enzyme-linked immunoassay (ELISA) and effects of melatonin administration on algal growth, Biol. Rhythm Res. (1999) in press.

[27] Lüning K., Kadel P., Bartsch I., Melatonin content of the intertidal marine macroalgae Chondrus crispus and Petalonia fascia at the island of Sylt, North Sea, Biol. Rhythm Res. (1999) in press. 
[28] Manchester L.C., Poeggeler B., Alvares F.L., Ogden G.B., Reiter R.J., Melatonin immunoreactivity in the photosynthetic prokaryote, Rhodospirillum rubrum: implications for an ancient antioxidant system, Cell. Mol. Biol. Res. 41 (1995) 391-395.

[29] Menendez-Pelaez A., Melatonin and other indoles in the rodent Harderian glands: regulation and physiological significance, Adv. Pineal Res. 4 (1990) 75-80.

[30] Menendez-Pelaez A., Buzzell G.R., Harderian gland indoles, in: Webb S.M., Hoffman R.A., Puig-Domingo M.L. (Eds.), Harderian Glands, Porphyrin Metabolism, Behavioral and Endocrine Effects, Springer, Berlin, 1992, pp. 219-234.

[31] Poeggeler B., Hardeland R., Detection and quantification of melatonin in a dinoflagellate, Gonyaulax polyedra. Solutions to the problem of methoxyindole destruction in non-vertebrate material, J. Pineal Res. 17 (1994) 1-10.

[32] Poeggeler B., Balzer I., Fischer J., Behrmann G., Hardeland, R., A role of melatonin in dinoflagellates?, Acta Endocrinol. 120 (suppl. 1) (1989) 97.

[33] Poeggeler B., Balzer I., Hardeland R., Lerchl A., Pineal hormone melatonin oscillates also in the dinoflagellate Gonyaulax polyedra, Naturwissenschaften 78 (1991) 268-269.

[34] Reece S., Wong J.Y.T., Indoleamine-induced encystment of symbiotic dinoflagellates, CAPS News Commun. 14 (suppl. 2) (1995) 26.

[35] Reiter R.J., Melchiorri D., Sewerynek E., Poeggeler B., Barlow-Walden L., Chuang J.-I., Ortiz G.G., Acuña-Castroviejo D., A review of the evidence supporting melatonin's role as an antioxidant, J. Pineal Res. 18 (1995) 1-11.
[36] Sprenger J., Hardeland R., Fuhrberg B., Han S.-Z., Melatonin and other 5-methoxylated indoles in yeast: Presence in high concentrations and dependence on tryptophan availability, Cytologia (1999) in press.

[37] Tilden A.R., Becker M.A., Amma L.L., Arciniega J., McGaw A.K., Melatonin production in an aerobic photosynthetic bacterium: An evolutionarily early association with darkness, J. Pineal Res. 22 (1997) 102-106.

[38] Tsim S.-T., Wong J.T.Y., Wong Y.H., Calcium ion dependency and the role of inositol phosphates in melatonin-induced encystment of dinoflagellates, J. Cell Sci. 110 (1997) 1387-1393.

[39] Tsim S.-T., Wong J.T.Y., Wong Y.H., Regulation of calcium influx and phospholipase $C$ activity by indoleamines in dinoflagellate Crypthe codinium cohnii, J. Pineal Res. 24 (1998) 152-161.

[40] Van Tassel D.L., Li J., O'Neill S.D., Melatonin: Identification of a potential dark signal in plants, Plant Physiol. 102 (suppl. I) (1993) 659.

[41] Vivien-Roels B., Pévet P., Melatonin: presence and formation in invertebrates, Experientia 49 (1993) 642-647.

[42] Werner A., Lüning K., Does the vertebrate pineal hormone melatonin regulate circadian and circannual growth rhythm in the brown alga Pterygophora californica?, Biol. Rhythm Res. (1999) in press.

[43] Wong J.T.Y., Wong Y.H., Indoleamine-induced encystment in dinoflagellates, J. Mar. Biol. Assoc. U.K. 74 (1994) 467-469. 